\title{
Gestation Length and Litter Size of New Zealand White Grade Rabbit
}

\author{
A. Setiaji ${ }^{*}$ D. A. Lestari, S. Sutopo, Y. S. Ondho and E. Kurnianto \\ Departement of Animal Science, Faculty of Animal and Agricultural Sciences, \\ Universitas Diponegoro, Tembalang Campus, \\ Semarang, 50275, Central Java, Indonesia \\ Corresponding Author: asepsetiaji@lecturer.undip.ac.id
}

\begin{abstract}
The purpose of this study was to examine performances and factors that influence the gestation length (GL) and litter size (LS) of New Zealand White Grade (NZW Grade) rabbits. Reproduction records of NZW Grade rabbits were taken from April 2020 to March 2021. Data analysis was carried out using the general linear model (GLM) procedure from Statistical Analysis System (SAS) University Edition V.6p.2. software. Farm showed a significant effect $(\mathrm{P}<0.001)$ on LS and significant season $(\mathrm{P}<0.05)$ on GL and LS. GL in the rainy season (31.56) was shorter than the GL in the summer (32.26), but the LS in the rainy season (7.06) was greater than the LS in the rainy season (6.37). Maintenance management should be improved to reduce the impact of the season on GL and LS NZW Grade rabbits.
\end{abstract}

Keywords: General linear model; gestation lenght; litter size; New Zealand White Grade rabbit; reproduction records.

\section{INTRODUCTION}

The New Zealand White Grade Rabbit (NZW Grade) is a broiler-type rabbit developed by most breeders in Central Java. The NZW Grade is the result of a cross between a New Zealand White rabbit imported from the United States in the last ten years with a rabbits that have been adapted to the tropical climate. NZW Grade rabbit have fast growth rates, good carcass quality, and well adapted in tropical environments. According to these permormances NZW Grade have potential for meat producing livestock.

Reproductive performance is important in determining the success of rabbits breeding. The breed of rabbits should have a high fertility and birth rates and good ability to raise their offsprings (Widitania et al., 2016). Reproductive traits that used in assessing the reproductive ability of female rabbits were gestation length, litter size, and mortality of offspring.

Litter size (LS) is a reflection of the fertility of female rabbits and their ability to take care of their offspring (McNitt et al., 2013). The average LS of rabbits in have been reported in Indonesia was range from 7.2 to 8.1 (Brahmantiyo et al., 2017). According to Lebas et al. (1997), LS will increase in the second parity by $10 \%-20 \%$, then will decrease in the third parity and remain in the fourth parity futher decrease in the fifth parity; and so on. LS was influenced by several factors including the breeds, mating management, the fisiologis condition of the female feed quality during pregnancy period and
Low quality of sperm tend to produce fewer offspring (Utami et al., 2019).

Gestation length (GL) of rabbits is influenced by several factors such as breeds (McNitt and Moody, 1991), climate, and weather (Ferraz et al., 1991; Farghaly, 1996). The average GL in rabbits is 32 days, ranging from 27-35 days (Ehiobu et al., 1997). McNitt et al. (1997) reported that longer GL of rabbit in summer was follow with fewer number of LS. This study aimed to examine performance and factors that influence GL and LS of NZW Grade rabbits.

\section{MATERIAL AND METHODS}

\section{Data collection}

Reproduction records of female NZW Grade rabbits were obtained from 8 farms in Semarang and Kendal Regencies, Central Java Province. Data collection was carried out from April 2020 to March 2021. A total of 182 data were obtained from 74 female rabbits from first to fifth parity. The parameters observed were GL and LS. GL is period from matting to partus, while LS is the number of offsping birth in one parity.

\section{Statistical analysis}

Data analysis was performed using Statistical Analysis System (SAS) University Edition V.6p.2. software. General Linear Model (GLM) procedur (SAS Institute Inc., Cary, NC, USA) was used to determine the effect of farm, season, and parity as well as the interaction between them for the GL and LS. 
Statistical models was used as follow:

$$
\boldsymbol{y}_{i j k}=F_{i}+S_{j}+P_{k}+e_{i j k}
$$

where: $y_{i j k}$ is the observed value of a dependent variable (GL/LS), the $F_{i}$, the ith effect of farm, $S_{j}$, the jth effect of the season, $P_{k}$, the kth effect of parity and $e_{i j k}$ is the random residual of $y_{i j k}$.

\section{RESULTS AND DISCUSSION}

The results of significant factors on GL presented in table 1 . The season had a significant effect $(\mathrm{P}<0.001)$ on GL, while farm and parity had no statistical effect on GL The interaction between these factors did not affect on GL and LS, so there is no discussion about the interaction. The results of the analysis were in agreement with the studies reported by Boyd and Bray (1989); Ferraz et al. (1991) and Farghaly, (1996) who stated that the reproduction of rabbits was influenced by the seasons which has an impact on gestation and lactation of female rabbit. Lebas et al. (1986), reported that season is ones of the external factors that play a role in the physiological and reproductive conditions of female rabbits. Parity has no significant effect on GL but GL will be longer in older female rabbits (Tůma et al., 2010). The Least-squares means analysis of GL in the rainy season is 31.56 whereas, in the summer is 32.26 (Table 3). These results are in accordance with McNitt et al. (1997) reported that GL of rabbit in the summer is longer than which in the winter. Fayeye and Ayorinde, (2010) reported different results of local rabbits in Nigeria, where; GL of rabbits in summer (32.03) was shorter than that in the rainy season (32.62). Overall, the GL of the NZW Grade rabbit in this study was longer than the GL of the New Zealand White Purebreed Rabbit (30.4) by Ghosh et al. (2003) and (31.9) by Fadare and Fatoba (2018).

Table 1. Significance of factors affecting gestation length and litter size

\begin{tabular}{cccccc}
\hline & & \multicolumn{2}{c}{ Gestation length } & \multicolumn{2}{c}{ Litter size } \\
\cline { 2 - 6 } Factor & $\mathrm{db}$ & $\mathrm{F}$ Value & $\operatorname{Pr}>\mathrm{F}$ & $\mathrm{F}$ Value & $\operatorname{Pr}>\mathrm{F}$ \\
\hline Farm & 7 & 1,02 & 0,4173 & 3,94 & 0,0005 \\
Season & 1 & 3,95 & 0,0484 & 6,27 & 0,0132 \\
Parity & 4 & 0,06 & 0,9935 & of 1.52 & 0,1974 \\
\hline
\end{tabular}

Description $: \mathrm{db}=$ degrees of freedom; $\mathrm{Pr}=$ probability

Farm and season were significant $(\mathrm{P}<0.05)$ on LS, while parity was no statistically significant on LS in NZW Grade rabbits. This result shows that besides being influenced by genetics, LS is strongly influenced by farm management (Table 2). Farm managements are including breeding, feeding, and housing management. Eiben et al. (2001) reported that female rabbits have been fed a controlled diet showed good reproductive performance, large number of LS and high milk production. Mating management also affected on LS, female rabbits mated during standing heat, with characteristics swollen and red vulva was increased the conception rate and number of LS (Maertens, 1998; Szendrő et al., 2006). Rebollar et al. (2009) reported that female rabbits reared with semiintensive systems showed better reproductive performance than in the intensive systems.

Table 2. Least squares means for gestation length and litter size on the different farm

\begin{tabular}{cccc}
\hline Farm & $\mathrm{N}$ & $\mathrm{GL}$ & $\mathrm{LS}$ \\
\hline 1 & 38 & 31,89 & 5,36 \\
2 & 24 & 31,85 & 6,89 \\
3 & 37 & 31,31 & 5.96 \\
4 & 11 & 31,85 & 6.01 \\
5 & 17 & 32,63 & 7,11 \\
6 & 15 & 32,19 & 5,07 \\
7 & 26 & 31,29 & 4.88 \\
8 & 14 & 32,34 & 7,30 \\
\hline
\end{tabular}

Description : $\mathrm{N}=$ number of samples; $\mathrm{GL}=$ gestation length ; $\mathrm{LS}=$ litter size 
Table 3. Least squares means for GL and LS on different season and parity

\begin{tabular}{ccccc}
\hline Factor & Category & N & GL & LS \\
\hline Season & rain & 104 & 31,56 & 7,06 \\
& dry & 78 & 32,26 & 6,37 \\
\hline \multirow{3}{*}{ Parity } & 1 & 72 & 31,97 & 6.69 \\
& 2 & 56 & 31,95 & 5,82 \\
& 3 & 31 & 31,76 & 6.11 \\
& 4 & 19 & 32,00 & 5,83 \\
& 5 & 4 & 31,87 & 5,90 \\
\hline
\end{tabular}

Description : $\mathrm{N}=$ number of samples; ; $\mathrm{GL}=$ gestation length; $\mathrm{LS}=$ litter size

The Least-squares means of LS in rainy season was 7.06 while in the summer was 6.37 (Table 3). These results are in accordance with Ayyat et al. (1995) that reported number of LS in summer was fewer number of LS in the winter. Fayeye and Ayorinde, (2010) reported different results where number of LS in the summer $(5,12)$ was larger than number of LS in the rainy season $(4,4)$ for local rabbits in Nigeria. The LS of the NZW Grade rabbits in this study was fewer than the LS of the New Zealand White, Hyla, and Hycole Rabbits (ranged from 7.2 to 8.1) (Brahmantiyo et al., 2017).

\section{CONCLUSION}

Reproductive management of rabbits was difficult to formulated. The results of this study can be considered, among others: farm, feeding, and mating managements should be standardized to improve the reproductive performance of female NZW Grade rabbits. Hausing manipulation such as lighting and temperature can could be done as an effort to reduce the effect of season on the reproductive performance of female rabbits.

\section{ACKNOWLEGMENT}

This research was funded by Hibah Dana Penelitian Universitas Diponegoro Semarang with Contract No. 36/UN7.5.5.2/PP/2021 dated March $1,2021$.

\section{REFERENCES}

Ayyat, M.S., Marai, I.F.M. and Gh.A. El-Sayiad. 1995. Genetic and non-genetic factors affecting milk production and preweaning litter traits of New Zealand White does under egyptian conditions. world rabbit science 3:119-124.
Brahmantiyo, B., Raharjo Y.C. dan L.H. Prasetyo. 2017. Performa produksi kelinci HyCole, New Zealand White dan persilangan timbal baliknya. Jurnal Ilmu Ternak dan Veteriner. 22(1):16-23.

DOI:10.14334/jitv.v22i1.1590

Boyd, I.L. and C.J. Bray. 1989. Nutritional ecology of the wild rabbit an input to timing of reproduction. Proceeding of Nutrition Society. 48:81-91. DOI: $10.1079 /$ pns 19890012

Ehiobu, N.G., Utim A. and S.D. Gwaza. 1997. Some observations on reproductive performance of rabbits obtained in semihumid tropicalconditions in Nigeria. World Rabbit

Science.5:47-49. DOI: https://doi.org/10.4995/wrs.1997.317

Eiben, Cs., Kustos, K., Kenessey, Á., Virág Gy. and Zs. Szendrö. 2001. Effect of different feed restriction during rearing on production performance in rabbit does. World Rabbit Science. 9:9- 14. DOI:10.4995/wrs.2001.440

Fadare, A.O. and T.J. Fatoba. 2018. Reproductive performance of four breeds of rabbit in the humid tropics. Livestock Research for Rural Development. Volume. 30: article 114. http://www.lrrd.org/lrrd30/7/delod30 114.html

Farghaly, H.M. 1996. Analysis of incidence of pre and post mature gestations in rabbit populations. Proceeding $6^{\text {th }}$ World Rabbit Congress 9-12 July 1996. Toulouse, France. $\quad \mathrm{p}$ 273-277. http://www.publications.zu.edu.eg/Pages/P ubShow.aspx?ID=4127\&\&pubID=2pdf

DOI: https://doi.org/10.4995/wrs.1995.250 
Fayeye, T.R. and K.L. Ayorinde. 2010. Effects of season, generation, number of mating, parity and doe number of teat on doe and litter birth characteristics in domestic rabbit. Research Journal of Animal and Veterinary Sciences, 5: 69.http://www.aensiweb.net/AENSIWEB/rj avs/rjavs/2010/6-9.pdf

Ferraz, J.B.S., Johnson R.K. and J.P. Eler. 1991. Effect of inbreeding on reproduction traits of Californian and New Zealand White rabbits. Journal of applied Rabbit Research. 15:211-217.

Ghosh S.K., Das A., Bujarbaruah K.M., Das Asit., Dhiman K.R. and N.P. Singh. 2008. Effect of breed and season on rabbit production under subtropical climate. World Rabbit Science.16:29-33.

DOI: https://doi.org/10.4995/wrs.2008.638

Lebas, F., P. Coudert, R. Rouvier and H.D. Rochambeau. 1986. The rabbit husbandry, health and production. Food and Agriculture Organization of The United Nation, Rome. Italy. https://www.researchgate.net/publication/3 8977233_The_Rabbit_Husbandry_Health_ and Production

Lebas, F., P. Coudert, H. De Rochambeau, and T.G. Thebault. 1997. The Rabbit, Husbandry, Health and Production, New Revised Version. Food and Agriculture Organization of The United Nation, Rome. https://www.doc-developpementdurable.org/file/Elevages/Lapins/The $\% 20$ Rabbit_Husbandry health\%20and\%20protection_FAO.pdf

McNitt, J. I. and G.L. Moody. 1991. Gestation length of four medium breeds of rabbits in Louisiana. Journal of applied Rabbit Research. 14:80-82.
McNitt, J. I., Mellad K.E., Simon G., Negatu Z. and S.D. Lukefahr. 1997. Efficacy of prostlagandin $\mathrm{F}_{2 \mathrm{a}}$ and its analogs in enhancing reproductive efficiency of doe rabbits. World Rabbit Science. 5:155-159. DOI: https://doi.org/10.4995/wrs.1997.336

McNitt, J. I., Lukefahr, S. D., Cheeke, P. R. and N.M. Patton. 2013. Rabbit production, 9th Ed. CABI, Wallingford. U.K.

Rebollar, P.G., Pérez-Cabal, M.A., Pereda, N., Lorenzo, P.L., Arias-Álvarez, P. and P. García-Rebollar. 2009. Effects of parity order and reproductive management on the efficiency of rabbit productive systems. Livestock Science, 121:227-233. https://doi.org/10.1016/j.livsci.2008.06.01 8

SAS. 2011. SAS/STAT User's Guide (Release 9.3). SAS Inst. Inc., Cary NC, USA. Availableat

https://citeseerx.ist.psu.edu/viewdoc/down load?doi=10.1.1.226.6407\&rep=rep1\&typ e $=$ pdf Accessed January 2021.

Tůma, J., E. Tůmová, E. and V. Valášek. 2010. The effect of season and parity order on fertility of rabbit does and kit growth. Czech Journal of Animal Science. 55:330336. https://doi.org/10.17221/317/2009CJAS

Utami, P., Samsudewa, D. dan C.M.S. Lestari. 2019. Pengaruh perbedaan sistem perkawinan terhadap lama bunting dan litter size Kelinci New Zealand White. https://doi.org/10.31186/jspi.id.14.1.70-74

Widitania, S. Ondho, Y.S. dan C.M.S. Lestari. 2016. Korelasi antara bobot badan induk dengan litter size, bobot lahir dan mortalitas anak kelinci New Zealand White. Jurnal Ilmu-ilmu Peternakan. 26(2):4248. http://dx.doi.org/10.21776/ub.jiip.201 6.026.02.6 